DOI: https://doi.org/10.47405/mjssh.v5i11.539

\begin{tabular}{|c|c|}
\hline 4 & Malaysian Journal of Social Sciences and Humanities (MJSSH) \\
\hline Malaysian Journal of & Volume 5, Issue 11, November 2020 \\
\hline (MJ-SSH) & e-ISSN : 2504-8562 \\
\hline & $\begin{array}{l}\text { Journal home page: } \\
\text { www.msocialsciences.com }\end{array}$ \\
\hline
\end{tabular}

\title{
Pengangguran dalam kalangan Tenaga Kerja Semasa Wabak COVID-19
}

\author{
Abdul Rashid Aziz @Dorashid1 \\ ${ }^{1}$ Fakulti Kepimpinan dan Pengurusan, Universiti Sains Islam Malaysia (USIM) \\ Correspondence: Abdul Rashid Aziz @Dorashid (rashid@usim.edu.my)
}

\begin{abstract}
Abstrak
Wabak COVID-19 yang melanda Malaysia dan dunia telah memberi impak yang besar kepada sistem politik, ekonomi, sosial, kesihatan, dan pendidikan negara. Ekoran daripada wabak yang berlaku, kerajaan Malaysia telah mengumumkan pelaksanaan Perintah Kawalan Pergerakan (PKP) kepada rakyat bermula 18 Mac 2020 sekaligus memberi impak terhadap sektor pekerjaan. Hal ini kerana, banyak sektor pekerjaan yang terpaksa menghentikan operasi serta merta dalam usaha mengekang penularan wabak COVID-19 daripada terus menular dalam masyarakat. Bahkan, penutupan perniagaan semasa PKP telah menyebabkan banyak syarikat tidak dapat menampung kos perbelanjaan termasuklah gaji pekerja hingga menyebabkan syarikat terpaksa membuang pekerja. Natijahnya berlaku kenaikan kadar pengangguran pada suku tahun pertama iaitu 3.9 peratus berbanding 3.3 peratus pada tahun 2019 (laporan Statistik Tenaga Buruh, 2020). Kajian ini menggunakan metod kajian perpustakaan dengan meninjau sorotan literatur bagi mengenal pasti impak COVID-19 terhadap tenaga kerja, model dan faktor yang mempengaruhi kobolehdapatan pekerjaan semasa wabak COVID-19 dalam mengatasi masalah pengangguran. Seterusnya dapatan dan perbincangan utama tertumpu kepada penerokaan faktor yang mempengaruhi kebolehdapatan kerja semasa COVID-19 seperti program kerjaya, insentif untuk menjana pendapatan dan inisiatif yang dilakukan oleh pihak kerajaan untuk membantu sektor pekerjaan serta kemahiran tenaga kerja yang sesuai dengan keperluan masakini.
\end{abstract}

Kata Kunci: pengangguran, tenaga kerja, kerjaya, COVID-19

\section{The Unemployment among Employees during Pandemic COVID-19}

\begin{abstract}
Pandemic COVID-19 which strucked Malaysia and the whole world gave major impacts on the country's political, economic, social, health, and education systems. Following the outbreak, Malaysian government announced the implementation of the Movement Control Order (MCO) to the citizen starting March 18, 2020 which affect the employment sector. This is because many employment sectors had to stop their operations immediately in an effort to curb the spread of the COVID-19 from continuing to spread in society. In fact, the sudden closure of the business during MCO had caused many companies to be unabled to cover the cost of expenses, including employees' salaries, forcing them to lay off their workers. As a result, the unemployment rate increased to 3.9 percent in the first quarter of the year as compared to 3.3 percent in 2019 (Labor Statistics report, 2020). This study used the library research method by reviewing the literature review of other previous study to identify the impact of COVID-19 on the workforce, models and factors that influence the availability of the employment during COVID-19 outbreak in overcoming the unemployment. Subsequently, key findings and discussions were mainly focused on the exploration of factors influencing the current job
\end{abstract}


availability during COVID-19 such as career programs, incentives to generate income and initiatives undertaken by the government to assist the employment sector as well as manpower skills which appropriate to current needs.

Keywords: unemployment, manpower, career, COVID-19

\section{Pengenalan}

Umum mengetahui pada penghujung tahun 2019, seluruh dunia telah digemparkan dengan penularan wabak COVID-19 yang mana wabak ini mula dikesan berlaku di Wuhan, China. Pada 11 Mac 2020, Pertubuhan Kesihatan Sedunia (WHO), telah mengisytiharkan wabak ini sebagai pandemik setelah ia merebak secara global melibatkan kebanyakan negara di seluruh dunia (Cucinotta \& Vanellli, 2020).

Penularan wabak Covid-19 telah berlaku dengan pantas. Menurut laporan daripada Pertubuhan Kesihatan Sedunia (WHO) pada 10 Oktober 2020 menunjukkan jumlah kes COVID-19 telah mencecah 36 juta dengan lebih dari 1 juta kematian diseluruh dunia. Di Malaysia jumlah kes positif telah mencecah angka 15,096 dan kematian sebanyak 155 orang (Laporan Statistik Kementerian Kesihatan Malaysia, 2020) sekaligus wabak yang melanda Malaysia ini telah memberi kesan yang sangat besar kepada sistem politik, ekonomi, sosial, kesihatan dan pendidikan negara.

Krisis wabak COVID-19 yang meningkat dan menjangkiti rakyat Malaysia menyebabkan Kerajaan terpaksa mengisytiharkan Perintah Kawalan Pergerakan (PKP) sebagai langkah untuk memutuskan rantaian pandemik COVID-19 daripada terus merebak. Perintah Kawalan Pergerakan (PKP) yang bermula pada 18 Mac 2020 telah dilaksanakan secara berperingkat sehingga ke fasa terakhir Perintah Kawalan Pergerakan Pemulihan (PKPP) yang berakhir pada 31 Disember 2020. Polemik dari wabak yang berlaku telah mencetuskan implikasi besar kepada setiap aspek iaitu politik, ekonomi dan sosial serta mendapat pelbagai reaksi negatif masyarakat. Ini kerana, perintah yang dikeluarkan itu menyebabkan penduduk Malaysia perlu tinggal di rumah dan tidak lagi dibenarkan untuk melaksanakan tugasan harian di luar seperti kebiasaan. Justeru, senario yang berlaku memerlukan individu beradaptasi dan menyesuaikan diri dengan norma baharu ini (Abdul Rashid Aziz, 2020).

Salah satu impak dari PKP yang dilaksanakan di negara ini adalah dari segi kesan terhadap sektor pekerjaan. Hal ini kerana, banyak sektor pekerjaan yang terpaksa ditutup sebagai usaha membantu kerajaan mengekang penularan wabak COVID-19 daripada terus menular dalam masyarakat. Kebanyakan syarikat, operasi perniagaan, organisasi swasta serta kerajaan ditutup serta merta. Bahkan, penutupan perniagaan semasa PKP telah menyebabkan banyak syarikat tidak dapat menampung kos perbelanjaan termasuklah gaji pekerja hingga menyebabkan syarikat terpaksa membuang pekerja (Jabatan Perangkaan Negara, 2020).

Selain itu, sektor yang diberikan pengecualian daripada pelaksanaan PKP untuk beroperasi tetap mendapat impak buruk disebabkan perlu beroperasi mengikut Prosedur Operasi Standard atau Standard Operation Procedure (SOP) yang begitu ketat dan memakan kos tambahan. Tambahan pula, kurangnya kehadiran pelanggan disebabkan pematuhan kepada Perintah Kawalan Pergerakan (PKP) merupakan faktor terbesar kebanyakkan syarikat mahupun pemilik perniagaan mengambil keputusan menutup premis perniagaan mereka. Malah, sekatan perjalanan dan penutupan sempadan telah menyebabkan sektor pelancongan terjejas teruk serta memberi kesan kepada sektor-sektor lain seperti perhotelan, industri makanan, pengangkutan dan banyak lagi (Jabatan Perangkaan Negara, 2020).

\section{Pengangguran Semasa WabakCOVID-19.}

Malaysia telah merangka wawasan 2020 sebagai pelan lonjakan kemajuan negara, namun pandemik COVID-19 yang berlaku telah memberi implikasi yang besar kepada sektor ekonomi dan pembangunan negara. Sektor pekerjaan antara sektor yang terjejas dengan kenaikan kadar pengangguran pada suku tahun pertama iaitu 3.9 peratus berbanding 3.3 peratus pada tahun 2019 
DOI: https://doi.org/10.47405/mjssh.v5i11.539

(laporan Statistik Tenaga Buruh, 2020). Bahkan dalam data perangkaan juga didapati jumlah penganggur telah meningkat kepada 610 ribu orang (17.1 peratus) berbanding 521 ribu orang pada bulan yang sama tahun 2019. Kadar pengangguran yang tinggi pada bulan Mac 2020 ini adalah dipengaruhi oleh impak negatif PKP ke atas pasaran buruh. Statistik ini dianggarkan terus bertambah berikutan penularan wabak COVID-19 yang dilihat masih belum reda.

Di samping itu, banyak pekerja mengalami pengangguran disebabkan sektor pekerjaan yang terjejas apabila PKP dilaksanakan termasuklah sektor pelancongan, penerbangan, perniagaan, industri kreatif, perumahan, pembuatan, perniagaan, sumber manusia, perubatan swasta, perkhidmatan profesional, pertubuhan bukan kerajaan (NGO), pertanian dan perladangan (Mohd Zaky Zainudin, 2020). Kajian yang dibuat oleh sebuah firma penyelidikan pasaran (IPSOS) mendapati bahawa kebimbangan terhadap pengangguran meningkat kepada 40 peratus pada jumlah tertinggi semasa COVID-19 berbanding tahun sebelumnya. Data tinjauan yang dibuat ini juga menunjukkan sebanyak 62 peratus rakyat Malaysia mencatatkan kebimbangan terhadap wabak COVID-19 yang turut sama mempengaruhi ekonomi negara disebabkan kebimbangan untuk membuat sebarang bentuk aktiviti luar termasuklah bekerja (Laporan IPSOS, 2020). Ini ditambah dengan sekatan pergerakan semasa PKP. Oleh itu, penularan wabak COVID-19 bukan sahaja melumpuhkan ekonomi di Malaysia, malah di seluruh dunia. Akibatnya, ramai pekerja telah diarahkan mengambil cuti tanpa gaji selama beberapa bulan, dipotong gaji antara 20 hingga 50 peratus, malahan ada pekerja yang berhadapan dengan masalah ketidakpastian dalam pekerjaan apabila syarikat menghentikan operasi mereka. Ini juga menyebabkan tenaga kerja mengalami masalah pemberhentian kerja dan sebagai akibatnya kadar pengangguran meningkat (Sinar Harian, 2020).

Rajah 1: Impak PKP terhadap Pengangguran dan Ekonomi

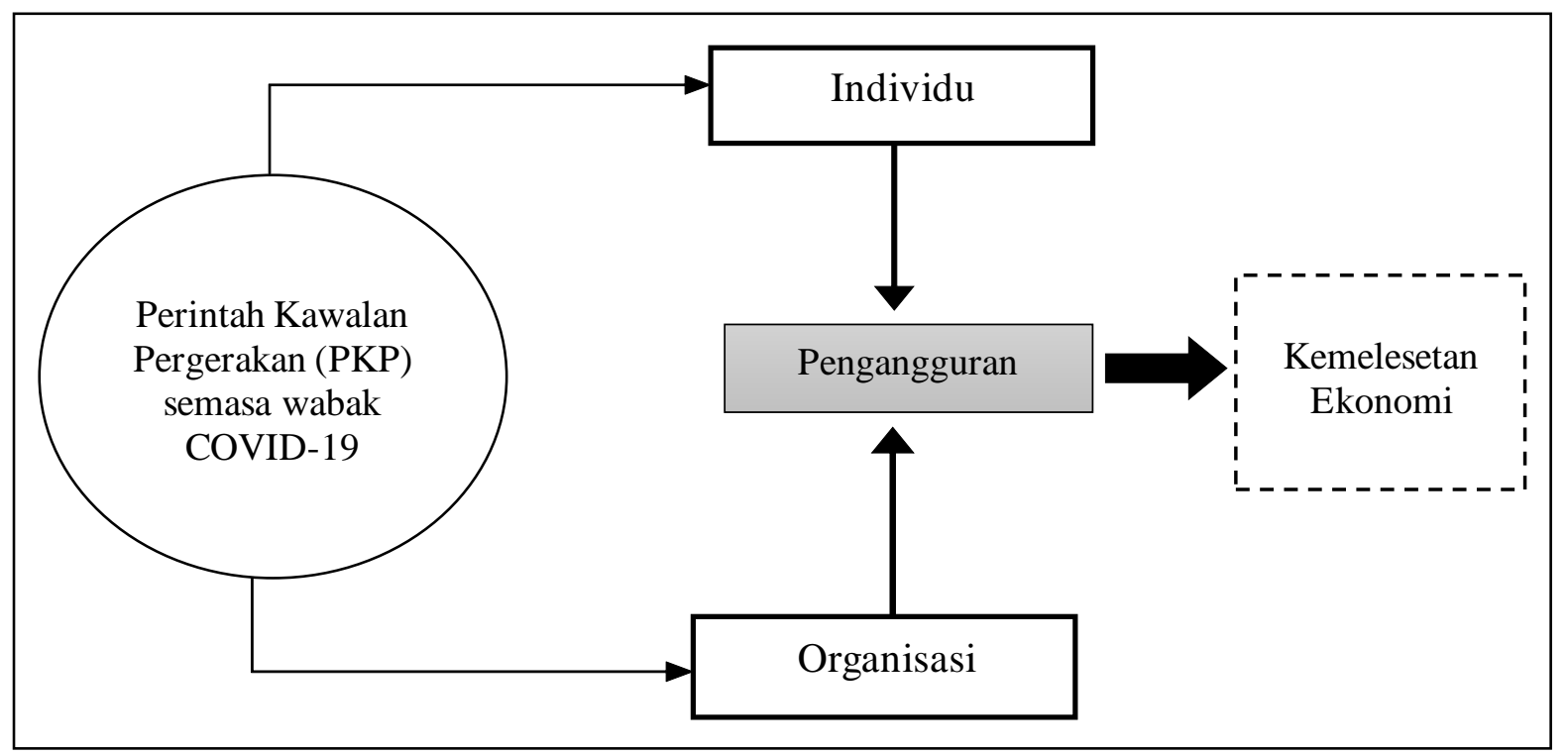

\section{Sorotan Literatur}

Pekerjaan merupakan medium utama untuk memperolehi ganjaran kepada manusia bagi meneruskan kehidupan. Dalam bentuk hubungan timbal balas, tenaga kerja pula menjadi nadi yang menggerakkan sumber dan mengoperasikan sistem dalam sesebuah organisasi. Sumber manusia dilihat sebagai aset terpenting dalam meningkatkan kualiti perkhidmatan, produktiviti dan mutu kerja.

Pengangguran didefinisikan sebagai suatu keadaan di mana individu yang tergolong dalam kumpulan tenaga kerja dan ingin mendapatkan pekerjaan tetapi belum memperolehinya (Bradley, 2003). Pengangguran dikaitkan dengan ketidakseimbangan antara penawaran tenaga kerja dengan permintaan tenaga kerja. Sebahagian individu yang berjaya mendapatkan pekerjaan tergolong dalam kumpulan 
individu yang bekerja (employ), manakala selebihnya digolongkan sebagai penganggur (unemploy) bagi individu yang tidak berjaya mendapatkan pekerjaan.

Wabak COVID-19 telah mempengaruhi dan memberi impak kepada seluruh dunia secara mendadak. Robert et al. (2020) menyatakan bahawa untuk melambatkan proses penularan wabak ini, negara seperti Amerika Syarikat juga telah melaksanakan polisi penjarakan sosial dan kawalan pergerakan yang ketat di mana polisi ini telah menyebabkan banyak rakyatnya terpaksa menutup perniagaan dan diberhentikan kerja terutamanya dalam industri yang dianggap bukan permintaan. Ia telah memberi kesan terhadap ekonomi yang dapat dilihat melalui pergolakan dalam pasaran saham, lonjakan tuntutan insuran yang disebabkan oleh pengangguran dan penutupan pelbagai jenis perniagaan di seluruh negara (Robert et al., 2020). Perkara yang sama turut dinyatakan oleh Pertubuhan Buruh Antarabangsa (International Labor Organization, 2020) di mana pandemik COVID-19 ini telah menyebabkan pengenalan langkah-langkah sekatan yang ketat yang memberi kesan terhadap ekonomi global, termasuklah peningkatan kadar pengangguran di seluruh dunia. Walaupun kawalan pergerakan diperketatkan dan banyak individu terpaksa tinggal di rumah dan tidak boleh keluar bekerja, namun kajian dari Dingel dan Neiman (2020) dengan menggunakan data dari maklumbalas terhadap dua tinjauan Jaringan Maklumat Pekerjaan mendapati bahawa sekitar 37 peratus daripada pekerjaan dapat dilakukan dari rumah.

\section{Kerangka Teori ModelKebolehdapatan Kerja}

Di dalam membincangkan aspek kebolehdapatan kerja apabila seseorang sedang mengalami pengangguran, aspek kemahiran dan nilai merupakan elemen yang penting. Hal ini kerana, indikator seperti daya saing, kebolehan, nilai, kelulusan, kecekapan, kepakaran dan kemahiran adalah antara faktor dan ciri utama dalam menentukan seseorang mendapat pekerjaan disebabkan persaingan dalam pasaran tenaga kerja (Abd Rahim Rashid, 2006). Justeru, dua bentuk kerangka teori telah digabungjalin agar sesuai dengan pemahaman elemen nilai dan kemahiran yang diperlukan dalam situasi masalah pengangguran yang berlaku semasa COVID-19 ini. Kerangka tersebut ialah Model Suruhanjaya Pencapaian Kemahiran Berkeperluan (Model Secretary Commission on Achieving Necessary Skills atau SCANS) dan Teori Jangkaan-Nilai (Expectancy-Value Theory atau EVT).

Model Suruhanjaya Pencapaian Kemahiran Berkeperluan (Model Secretary Commission on Achieving Necessary Skills) atau Model SCANS yang dibangunkan pada tahun 1991 telah mendokumenkan kemahiran yang diperlukan dalam alam pekerjaan. Kemahiran ini digelar sebagai 'workplace know how' yang terdiri daripada dua bahagian iaitu kompetensi di tempat kerja dan kemahiran teras. Kompetensi di tempat kerja terbahagi kepada lima elemen iaitu sumber, kemahiran interpersonal, maklumat, sistem dan teknologi. Manakala, kemahiran teras terbahagi kepada tiga elemen iaitu kemahiran asas, kemahiran berfikir dan kualiti personal. Model ini telah ditambahbaik pada tahun 2000 di mana ia lebih berfokuskan kemahiran teknologi maklumat. Model ini dilihat bersesuaian untuk diaplikasikan dengan suasana wabak COVID-19 dan sejajar dengan Revolusi Industri 4.0 ini. oleh itu, elemen kecekapan dalam abad ke-21 (21st century literacy) dan pembelajaran sepanjang hayat ditambah ke dalam elemen kemahiran teras model SCANS ini.

Seterusnya dalam membincangkan aspek kompetensi di tempat kerja pula, perincian dalam model SCANS yang bersesuaian dengan situasi pandemik COVID-19 ialah elemen sumber yang merujuk kepada pengurusan masa, pengurusan kewangan, pengurusan bahan dan kemudahan serta pengurusan sumber manusia. Seterusnya elemen interpersonal yang merangkumi kemahiran dalam diri seseorang seperti bekerja dalam satu pasukan, memberi layanan dan perkhidmatan kepada pelanggan, kepimpinan, melakukan perundingan serta bekerja dengan kepelbagaian budaya. Kemahiran maklumat pula dibahagikan kepada kemahiran memperoleh dan menilai maklumat, menyusun dan mengekalkan maklumat, mentafsir dan komunikasi maklumat serta menggunakan komputer untuk memproses maklumat. Manakala, kemahiran memahami sistem ialah kemahiran seseorang untuk mengawasi dan memperbaiki prestasi serta menambah nilai dalam organisasi. Selain itu, rekabentuk sistem juga ialah aspek yang perlu ada dalam kemahiran sistem. Kemahiran yang terakhir ialah kemahiran teknologi yang merangkumi aspek memilih teknologi, menggunakan teknologi dalam tugas dan mengenal pasti masalah dalam teknologi. 
Selain daripada elemen kompetensi di tempat kerja, Model SCANS juga menekankan tentang kemahiran teras yang merupakan salah satu elemen penting bagi memastikan kebolehdapatan kerja seseorang. Dalam aspek kemahiran teras ini dapat dibahagikan kepada beberapa kemahiran yang perlu ada pada setiap pekerja iaitu kemahiran asas seperti membaca, menulis, pengiraan, mendengar dan pertuturan. Selain itu, kemahiran berfikir yang terbahagi kepada pemikiran kreatif, membuat keputusan dan penyelesaian masalah. Kemahiran teras juga menekankan elemen kualiti dalam diri individu antaranya ialah nilai bertanggungjawab, yakin diri, kemampuan bersosial, pengurusan diri, integriti dan jujur. Kesemua nilai ini merupakan elemen utama yang perlu ada bagi setiap pekerjaan.

Teori Jangkaan-Nilai atau Expectancy-Value Theory (EVT) yang diperkenalkan oleh Martin Fishbein pada pertengahan tahun 1970 ialah teori berasaskan kognitif-motivasi yang menghubungkan tahap atau kekuatan motivasi individu untuk berusaha mencapai tujuan tertentu berdasarkan jangkaan, nilai insentif dan kekuatan terhadap matlamat yang diinginkan tersebut. Contohnya, mencari pekerjaan untuk mendapatkan wang bagi sumber pendapatan dan kehidupan. Menurut Feather (1992) kekuatan sesuatu matlamat adalah berasal dari nilai (manfaat yang akan diperolehi) dari matlamat tersebut kerana nilai ini akan berfungsi sebagai kriteria yang menentukan sikap dan tingkah laku individu. Selain memberi perhatian kepada bagaimana individu menilai pekerjaan seperti aplikasi kemahiran, kepelbagaian kemahiran dan pengaruh pekerjaan (Feather \& O'Brien, 1986), EVT turut memberikan penekanan terhadap komitmen dalam pekerjaan. Dalam EVT, individu menganggur yang sangat menghargai pekerjaan bersedia melakukan pelbagai tingkah laku untuk mendapatkan pekerjaan dan sanggup menghabiskan seluruh tenaga fizikal, mental dan emosi dalam mencari pekerjaan (Kanfer et al., 2001).

Oleh itu, dalam membincangkan masalah pengangguran di Malaysia, gabungjalin model SCANS dan EVT amat relevan dalam membantu individu yang berhadapan dengan isu pengangguran. Individu yang sedang menganggur harus mempunyai matlamat terhadap pekerjaan meliputi elemen keyakinan diri, optimis dan meletakkan manfaat yang tinggi daripada pekerjaan. Justeru, ia akan menghasilkan dorongan (motivasi) ke arah mencapai pekerjaan yang diingini. Bahkan ia perlu ditambahnilai dengan kemahiran-kemahiran yang disebutkan dalam Model SCAN. Kesepaduan dalam gabungan ini adalah signifikan dalam menghasilkan pelan mengatasi kadar pengangguran yang kian meningkat semasa wabak COVID-19.

\section{Metod Kajian}

Kajian kualitatif ini menggunakan kaedah kajian perpustakaan untuk mencari maklumat sekunder yang berkaitan dengan wabak COVID-19. Maklumat-maklumat yang diperolehi adalah daripada pelbagai sumber seperti buku, jurnal, dan artikel akhbar serta majalah. Maklumat ini dikumpul dan disaring serta dianalisis menggunakan teknik analisis kandungan. Analisis kandungan terhasil apabila pengkaji mempunyai matlamat untuk menjalankan kajian literatur. Ia dimulakan dengan menyediakan latar belakang terhadap kandungan kajian literatur yang hendak dijalankan. Seterusnya pengkaji membaca dan memahami bahan literatur yang diperoleh. Akhirnya, pengkaji mengintegrasi bahan bacaan tersebut kepada pengetahuan yang dimiliki oleh pengkaji. Justeru, daripada analisis yang dijalankan, pengkaji dapat mengenalpasti impak COVID-19 terhadap sektor pekerjaan dan tenaga kerja serta faktor yang mempengaruhi kebolehdapatan pekerjaan semasa wabak ini melanda.

\section{Hasil Kajian dan Perbincangan Kajian}

Dalam berdepan dengan pelbagai implikasi wabak COVID-19 yang wujud dalam sektor pekerjaan ini, terdapat beberapa solusi yang boleh dilakukan. Misalnya, Federasi Kebangsaan Pekerja Belia Malaysia (FKPB) menyatakan bahawa majikan memerlukan tenaga kerja mahir bagi memenuhi permintaan industri selepas pandemik COVID-19 mengubah landskap pekerjaan. Ini kerana, pandemik COVID-19 telah mempercepatkan perlaksanaan Revolusi Industri 4.0. Justeru, kerajaan perlu meningkatkan kecekapan pasaran buruh dan mengubah pendidikan sedia ada untuk membantu belia memenuhi keperluan baru industri semasa dan selepas COVID-19 (Statistik Jabatan Perangkaan Malaysia, 2020). 
Selain itu, tenaga kerja yang 'marketable' dengan situasi COVID-19 yang berlaku pada hari ini juga penting. Malah, elemen kualiti, daya saing, kebolehan seseorang adalah antara faktor utama bagi mendapatkan pekerjaan dalam pasaran kerja yang kompetitif. Beberapa faktor kebolehdapatan kerja bagi mengatasi pengangguran telah dan sedang dijalankan seperti berikut;

\section{InisiatifKerajaan Membantu Sektor Pekerjaan dan Ekonomi Negara}

Berdasarkan Pakej Rangsangan Ekonomi Prihatin Rakyat (PRIHATIN) bernilai RM250 bilion yang telah diumumkan oleh YAB Perdana Menteri pada 27 Mac 2020, Kementerian Kewangan Malaysia telah melaksanakan Bantuan Prihatin Nasional (BPN) yang telah diperuntukkan sebanyak RM10 bilion bagi golongan rakyat Malaysia yang layak. Pembayaran BPN ini dibuat dalam dua fasa iaitu pada akhir bulan April dan Mei 2020 mengikut kelayakan berdasarkan jumlah pendapatan isi rumah dan status perkahwinan. BPN adalah salah satu bantuan yang disediakan oleh Kerajaan yang diberikan secara sekaligus (one-off) kepada golongan B40 dan M40. Pemberian BPN bagi golongan B40 adalah berdasarkan pengkalan data Bantuan Sara Hidup. Manakala BPN bagi golongan M40 adalah berdasarkan data percukaian Lembaga Hasil Dalam Negeri Malaysia (LHDNM). Pakej sokongan pendapatan merangkumi bantuan kewangan kerajaan kepada isi rumah dalam bentuk pemindahan wang tunai langsung atau pelepasan hutang serta pembayaran untuk utiliti ini bukan sahaja diimplementasikan di Malaysia, malah negara-negara lain yang terjejas teruk rentetan wabak COVID19 seperti Amerika Syarikat turut melaksanakannya (Ashraf, 2020).

Bantuan kerajaan ini antaranya untuk membantu individu yang dibuang kerja dan hilang punca pendapatan semasa wabak COVID-19 yang melanda (Wat Kamal, 2020). Bantuan ini juga untuk membantu rakyat dalam menampung keperluan sara hidup sekeluarga serta perbelanjaan persekolahan anak-anak. Ia seterusnya menjamin kelangsungan hidup rakyat dan ekonomi negara.

Selain itu, Kementerian Sumber Manusia juga telah dipertanggungjawabkan untuk melaksanakan program PENJANA KERJAYA melalui Pertubuhan Keselamatan Sosial Pekerja (PERKESO). Oleh yang demikian, setiap individu yang mencari pekerjaan dan pihak majikan boleh menarik nafas lega apabila kerajaan telah mengumumkan pelaksanaan PENJANA KERJAYA iaitu suatu program yang dijana bagi memberi insentif terhadap pengambilan pekerja. Program ini telah dilaksanakan bermula 15 Jun 2020. Tambahan dari itu, program ini dibangunkan bagi merangsang penjanaan sektor pekerjaan dan meningkatkan peluang pekerjaan ekoran kesan wabak COVID-19 yang membawa masalah pengangguran. Program Pelan Jana Semula Ekonomi Negara (PENJANA) ini juga secara tidak langsung dapat merangsang permintaan pekerjaan di kalangan majikan dan meningkatkan peluang pekerjaan serta kebolehdapatan pekerjaan di kalangan pencari kerja tempatan sekaligus menangani masalah pengangguran di Malaysia (Berita Harian, 2020).

\section{Kemahiran Teknologi \& Pelaksanaan Program Kerjaya}

Industri berkaitan teknologi maklumat (IT), perkilangan, perbankan, perniagaan runcit dan penjagaan kesihatan masih menawarkan peluang pekerjaan baharu sepanjang penularan wabak COVID-19 berlaku. Kebanyakan syarikat mula terarah kepada pendigitalan dan menggunakan kaedah baharu dalam menjalankan perniagaan. Oleh itu setiap individu perlu melengkapkan diri dengan kemahiran teknologi atas talian (online) dan Internet of Thing (IoT). Dalam tinjauan yang dilakukan oleh Syarikat JobStreet (2020) pada bulan Mei 2020, didapati daripada 5,000 tenaga kerja di Malaysia, satu dari lima individu yang bekerja sebelum PKP telah diberhentikan kerja. Justeru, sebagai rakyat Malaysia setiap individu haruslah sentiasa prihatin, kuasai kemahiran terkini dan diperlukan dalam situasi sekarang dan mengambil peluang yang ditawarkan sama ada oleh Kerajaan atau badan bukan kerajaan (NGO) untuk mendapatkan peluang pekerjaan.

Program '\#WorkNow' juga diperkenalkan bagi membantu pencari kerja untuk mencari kerja sebagai salah satu inisiatif untuk membantu rakyat untuk kembali ke pasaran kerja dengan pantas. Inisiatif '\#WorkNow' yang dibuat merupakan sebahagian dari kempen \#TogetherAhead yang merupakan satu inisiatif dari portal pekerjaan JobStreet yang bermula sejak awal kemunculan wabak ini (Bernama, 2020). Pihak Syarikat JobStreet Malaysia telah menekankan bahawa inisiatif ini bertujuan 
mengurangkan kadar pengangguran di negara ini. Dengan memasukkan simbol hashtag (\#) di bahagian "Maklumat Tambahan" di profil laman sesawang JobStreet, individu yang sedang mencari pekerjaan dapat menunjukkan ketersediaan untuk bekerja kepada pihak majikan. Dalam masa yang sama, majikan juga dapat mengenal pasti pekerja yang sesuai dengan keperluan di tempat kerja. Program bantuan semasa COVID-19 untuk membantu masyarakat juga telah dibuat diluar negara. Misalnya, di Amerika Syarikat melalui kementeriannya telah mengadakan program seperti Program Makan Tengah hari Sekolah (National School Lunch Program), Program Sarapan Sekolah (School Breakfast Program) dan Program Penjagaan Pemakanan bagi Kanak-kanak dan Dewasa (Child and Adult Care Food) untuk hampir 35 juta orang kanak-kanak setiap hari serta memberikan bantuan nutrisi dan sokongan kewangan kepada individu dan institusi keluarga yang memerlukan ekoran dari kadar pengangguran yang meningkat (Joanne Guthrie, 2020).

\section{Pemberian InsentifuntukMenjana Pendapatan dan Kerja}

Selain daripada insentif pakej rangsangan ekonomi PRIHATIN, pihak kerajaan Malaysia juga mengumumkan moratorium pembayaran pinjaman dan bantuan penangguhan pinjaman. Penangguhan ini adalah sebahagian daripada Pakej Rangsangan Ekonomi Prihatin Rakyat (PRIHATIN) yang bertujuan untuk melindungi rakyat, menyokong perniagaan dan mengukuhkan ekonomi negara. Kajian yang dijalankan oleh Marinov (2020) mendapati bahawa moratorium yang disediakan bagi pembayaran pinjaman di Negara Kesatuan Eropah (Europian Union, EU) terutamanya di Bulgaria adalah tindakan yang sangat penting yang bertujuan untuk membawa kestabilan dan bantuan kepada sistem perbankan dan orang ramai. Di Malaysia, moratorium pembayaran pinjaman yang berkuatkuasa pada 1 April 2020 telah membantu individu yang terjejas, masyarakat dan sektor perniagaan dalam pelbagai perkara yang berpunca dari PKP dan pembekuan hampir semua aktiviti ekonomi dalam usaha memerangi penyebaran wabak COVID-19 (SME Corporation Malaysia, 2020). Di samping itu, moratorium pembayaran pinjaman yang ditetapkan juga adalah untuk mengurangkan beban kewangan bagi keduadua kumpulan (rakyat dan pihak bank). Dalam masa yang sama, ia dapat membantu masalah aliran tunai yang timbul dalam perniagaan akibat pelaksanaan PKP.

\section{Kesimpulan}

Impak dari wabak COVID-19 telah memberi kesan yang mendalam terhadap kerjaya seseorang. Ancaman yang paling ditakuti oleh golongan pekerja apabila pengumuman Perintah Kawalan Pergerakan (PKP) yang menyebabkan ramai individu kehilangan pekerjaan sama ada terpaksa berhenti kerja, diberi cuti panjang ataupun diberhentikan kerja. Ini kerana, kebanyakkan majikan terpaksa mengambil tindakan drastik memberhentikan pekerja yang sedia ada demi mengurangkan kerugian dan menjimatkan kos operasi mereka. Malah, pembukaan semula tempat kerja selepas memasuki fasa Perintah Kawalan Pergerakan Pemulihan (PKPP) telah menimbulkan banyak tekanan dan kegelisahan dalam kalangan ramai pekerja kerana wabak COVID-19 boleh menjadi salah satu faktor yang mengundang kepada ancaman bahaya kepada pekerja. Situasi ini boleh menyebabkan ramai individu terdedah kepada risiko jangkitan, khususnya kepada individu yang mempunyai masalah kesihatan kronik dan warga tua.

Pengurusan kerjaya yang baik dapat mengelakkan individu daripada mengalami tekanan semasa wabak COVID-19 ini yang seterusnya mengakibatkan gangguan fizikal, mental dan emosi. Persediaan awal untuk merancang kerjaya semula bagi mereka yang telah berhenti kerja atau diberhentikan kerja perlu dibuat bagi menampung aspek kewangan dan sara hidup yang kian meruncing semasa wabak melanda. Persediaan awal juga meliputi keupayaan mendidik hati untuk sentiasa bersabar dan redha dengan ujian yang dihadapi. Tuntasnya sepanjang wabak COVID-19 ini, individu, pekerja, pelajar, mahupun institusi keluarga perlu mengoptimumkan penggunaan masa yang ada di sepanjang tempoh PKP dengan sebaik mungkin. Walaupun dalam menghadapi pelbagai tekanan psikologi ekoran kehilangan sumber pendapatan, pekerjaan dan urusan kerja tergendala namun ia bukanlah asbab untuk terus berpeluk tubuh atau membiarkan hari yang berlalu dengan tekanan kerana setiap manusia mampu membuat pilihan dan perubahan. 


\section{Penghargaan}

Sekalung penghargaan ditujukan kepada Universiti Sains Islam Malaysia atas pembiayaan geran penyelidikan yang bertajuk "Faktor Yang Mempengaruhi Kesejahteraan Kendiri Terhadap Tekanan Psikologi Semasa Wabak Covid-19“(PPPI/COVID19_0120/FKP/051000/13820).

\section{Rujukan}

Abdul Rashid Aziz@Dorashid. (2020). Wabak COVID-19: Penyesuaian Kendiri terhadap Norma Baharu. Capaian pada 9 Oktober 2020 dari https://www.usim.edu.my/ms/berita/in-our-wordsms/wabak-covid-19-penyesuaian-kendiri-terhadap-norma-baharu/

Abd Rahim Abd Rashid. (2006). Ciri-ciri Graduan yang Marketable dan Berdaya Maju untuk Kemajuan Kerjaya Abad Ke-21. Kuala Lumpur: Utusan Publication \& Distributors.

Ashraf B. N. (2020). Economic impact of government interventions during the COVID-19 pandemic: International evidence from financial markets. Journal of behavioral and experimental finance, 27, 100371. https://doi.org/10.1016/j.jbef.2020.100371

Bradley R.S. (2003). The Economic Today (9th ed). New York: McGraw-Hill.

Bernama (3 Jun 2020). MTUC Harap Rancangan Berdaya Maju, Mapan Tangani Masalah Pekerja.

Berita Harian Online Capaian pada 10 Oktober dari https://www.bharian.com.my/berita/nasional/2020/06/696048/mtuc-harap-rancangan-berdayamaju-mapan-tangani-masalah-pekerja

Bernama (3 Jun 2020). Several industries continue to show growth, still hiring - Jobstreet. Dicapai pada 5 October 2020 daripada https://www.bernama.com/en/general/news_COVID19.php?id=1847551

Brooks, S. K., Dunn, R., Amlot, R., Rubin, G.J., \& Greenberg, N. (2018). A systematic, thematic review of social and occupational factors associated with psychological outcomes in healthcare employees during and infectious disease outbreak. Journal of Occupational and Environmental Medicine, 60(3), 248-257.

Cancelliere C, Donovan J, \& Stochkendahl M.J. (2016). Factors affecting return to work after injury or illness: Best evidence synthesis of systematic reviews. Chiropr Man Therap, 24(1), 24-32.

Cucinotta, D \& Vanelli. (2020). WHO declares Covid 19 a Pandemic. Acta Biomed. 91(1), 157-160.

Dingel, J.I., Neiman, B. (2020). How Many Jobs Can be Done at Home?. Unpublished manuscript.

Etuknwa A, Daniels K, Eib C. (2019). Sustainable return to work: a systematic review focusing on personal and social factors. J Occup Rehabil, 29(4),679-700.

Feather, N.T. (1992). Expectancy-value theory and unemployment effects. Journal of Occupational and Organizational Psychology, 65, 315-330.

Feather, N.T., \& O'Brien, G. (1986). A longitudinal analysis of the effects of different patterns of employment and unemployment on school-leavers. British Journal of Psychology, 77, 459-479.

Fishbein, M. (1967). A behavior theory approach to the relations between beliefs about an object and the attitude toward the object. In M. Fishbein (Ed.), Readings in attitude theory and measurement (pp. 389-400). New York: John Wiley \& Sons.

Goyal, K., Chauhan, P., Chhikara, K., Gupta, P., \& Singh, M. P. (2020). Fear of COVID 2019: First suicidal case in India. Asian Journal of Psychiatry, 49, e101989.

Gragnano A, Negrini A, Miglioretti M, \& Corbière M. (2018). Common psychosocial factors predicting return to work after common mental disorders, cardiovascular diseases, and cancers: a review of reviews supporting a cross-disease approach. J Occup Rehabil, 28(2),215-231.

Huang Y., \& Zhao N. (2020). Generalized anxiety disorder, depressive symptoms and sleep quality during COVID-19 outbreak in China: A web-based cross-sectional survey. Psychiatry Research, doi: 10.1016/j.psychres.2020.112954. Advance online publication.

International Labor Organization. (March 18, 2020). Almost 25 million jobs could be lost worldwide as a result of COVID-19, says ILO. Dicapai pada 5 Oktober 2020 dari https://www.ilo.org/global/about-the-ilo/newsroom/news/WCMS_738742/lang--en/index.htm

IPSOS Survey (2020, June 5). What worries the world: Coronavirus Concern Rebounds. Capaian pada 10 Oktober 2020 dari https://www.ipsos.com/en-my/what-worries-world-coronavirus-concernrebounds 
JobStreet (2020). JobStreet survey: Several industries continue to show growth, still hiring. Dicapai pada 6 Oktober 2020 daripada https://www.jobstreet.com.my/

Joanne Guthrie. (2020). Child nutrition programs report. United States Department of Agriculture Economic Research Service. Dicapai pada 6 Oktober 2020 dari https://www.ers.usda.gov/topics/food-nutrition-assistance/child-nutrition-programs/.

Kanfer, R., Wanberg, C., \& Kantrowitz, T. (2001). Job-search and employment: A personalitymotivational analysis and meta-analytic review. Journal of Applied Psychology, 86, 837-855.

Laporan Statistik COVID-19. (2020). Kementerian Kesihatan Malaysia. Capaian pada 10 Oktober 2020 dari http://COVID-19.moh.gov.my/

Li J-B, Yang A, Dou K, Cheung RY. (2020). Self-control moderates the association between perceived severity of the coronavirus disease 2019 (COVID-19) and mental health problems among the Chinese public. PsyCOVID.

Malaysia: Garis Panduan Dasar Kesihatan Mental Negara. Kementerian Kesihatan Malaysia. Capaian pada 5 Mei 2020 di https://www.moh.gov.my/

Marinov, M.T. (2020). Application Of The Moratorium Over The Payment Of Loans In Connection With The Covid-19 Pandemic And Its Impact On The National Security In The Republic Of Bulgaria. International Conference Knowledge-Based Organization. XXVI (20), 199-204.

Mohd Zaky Zainudin (2 Jun 2020). COVID-19: Kerajaan Analisis Kesan Terhadap Sektor Terjejas. Berita Harian Online. Capaian pada 10 Oktober 2020 dari https://www.bharian.com.my/berita/nasional/2020/06/695534/COVID-19-kerajaan-analisiskesan-ke-atas-sektor-terjejas

Pengarang (2020, 5 Mei). Bendung pengangguran akibat wabak COVID-19. Sinar Harian.Dicapai pada 6 Jun 2020 daripada https://www.sinarharian.com.my/article/82004/SUARA-SINAR/LidahPengarang/Bendung-pengangguran-akibat-wabak-COVID-19

Pertubuhan Kesihatan Sedunia-World Health Organization (2020). Capaian pada 8 Mei 2020 di https://www.who.int/emergencies/diseases/novel-coronavirus-2019

Pierce M., Hope H., Ford T., Hatch S., Hotopf M., John A., \& Abel K.M. (2020). Mental health before and during the COVID-19 pandemic: A longitudinal probability sample survey of the UK population. The Lancet Psychiatry. doi: 10.1016/S2215-0366(20)30308-4. Advance online publication.

Robert, W. F., Kenneth, C., Huanan, Xu. (2020). The Impacts of COVID-19 on Minority Unemployment: First Evidence from April 2020 CPS Microdata. Unpublished raw data.

Samantha M. B., Jenalee R. D., Stephanie. L-P, Sarah. E.W., Tiffany. K. (2020). Stress and parenting during the global COVID-19 pandemic. Child Abuse Negl. 2020 Aug 20 :104699. doi: 10.1016/j.chiabu.2020.104699. Advance online publication.

Secretary's Commission on Achieving Necessary Skill (SCANS).(1991). Skills and Task for Jobs. A SCANS Report for America 2000. Washington, D.C. U.S Department of Labour.

Sharina Ahmad. (2020). Is 30\% rental discount incentive sufficient? SME Corporation Malaysia. $\begin{array}{lllll}\text { Dicapai } & \text { pada } & 6 & \text { Oktober } & 2020 \\ \end{array}$ https://www.smecorp.gov.my/index.php/en/resources/2015-12-21-10-55-22/news/4133-is-30rental-discount-incentive-sufficient

Wang, C., Pan, R., Wan, X., Tan, Y., Xu, L., Ho, C. S., y Ho, R. C. (2020). Immediate Psychological Responses and Associated Factors during the Initial Stage of the 2019 Coronavirus Disease (COVID-19) Epidemic among the General Population in China. International Journal of Environmental Research and Public Health, 17(5).

Wartawan BH. (September 11, 2020). Kadar Pengangguran di Malaysia Terus Berkurangan. Berita

Harian Online. Dicapai pada 15 September 2020 daripada https://www.bharian.com.my/bisnes/lainlain/2020/09/730168/kadar-pengangguran-di-malaysia-terus-berkurangan

Wat Kamal Abas (October 8, 2020). Bajet 2021: Teruskan Bantuan Prihatin Nasional. Utusan Malaysia Online. Dicapai pada 5 Oktober 2020 daripada https://www.utusan.com.my/berita/2020/10/bajet-2021-teruskan-bantuan-prihatin-nasional/ 